Investigations

\title{
The Dependence of Photosynthetic Indices and the Yield of Spring Rape on Foliar Fertilization with Microfertilizers
}

\author{
Valentina A. Gulidova, Tatyana V. Zubkova, Vladimir A. Kravchenko and Olga A. Dubrovina \\ Bunin Yelets State University, 399770, Russia, Lipetsk oblast', Yelets, Kommunarov Str., 28, Russia
}

\author{
Article history \\ Received: 24-11-2017 \\ Revised: 28-11-2017 \\ Accepted: 16-12-2017 \\ Corresponding Author: \\ Valentina A. Gulidova \\ Bunin Yelets State University, \\ 399770, Russia, Lipetsk oblast', \\ Yelets, Kommunarov Str., 28, \\ Russia \\ Email:vgulidova@yandex.ru
}

\begin{abstract}
Application of fertilizers is included today into the cultivation intensive technologies, as one of the basic components providing for high crop yield. Today, the minimal tillage is widely used, which significantly reduces the choice of fertilizer application method in comparison with classical fertilizers. Therefore, the competent use of the remaining methods of feeding field crops becomes very important. An innovative solution to this problem is the use of foliar fertilization in agrotechnologies. The use of microfertilizers in the form of foliar fertilizers makes it possible to provide plants with the necessary set of microelements during the formation of reproductive organs, leading to the enrichment of seeds of agricultural crops with microelements, which has a positive effect on the seed material. As a result of the researches lead by us it has been established that the application of new microfertilizers (Brassitrel and Bortrac) contributed to an increase in such biometric parameters of spring rape as the number of pods and runaways, the number of grains in a pod, which in turn increased the yield.
\end{abstract}

Keywords: Rape, Microfertilizers, Yield, Photosynthesis

\section{Introduction}

In the implementation of the import substitution program, great importance is attached to the accelerated increase in the production of oil-bearing seeds and an increase in the resources of vegetable oil.

Rape is a valuable oil-bearing and fodder crop. By food and fodder advantages, it significantly exceeds many crops.

Rape seeds contain $40-45 \%$ of semi-drying oil and $20-30 \%$ of protein. The rape oil containing unsaturated (oleic, linolenic, lenol) acids is equated with olive oil due to its high-caloric value and taste. After refining it is used for food purposes.

The spring rape is a very grateful culture, which responds well to new innovative techniques in technology. One of these methods is the use of microfertilizers, which is especially relevant at the present time.

The use of microfertilizers is an integral part of measures to increase the yield of agricultural crops, since mineral and organic fertilizers are not enough for the normal development of plants.

The microfertilizers include a number of microelements, the role of which in plant nutrition is multifaceted and has not yet been fully studied.
Microelements accelerate the development of plants and the ripening of seeds, increase plant resilience to unfavorable conditions in the external environment and make them resistant to a number of fungi and bacterial diseases (Vlasyuk, 1969; Petrov and Seliverstov, 1998; Potutaeva, 1963; Rinkis, 1975; Sinyagin, 1970; Yagodin, 1989; Belikov and Dmitriyeva, 1992).

The content of the micronutrients in the soil is very low. Soils with respect to microelements have high absorptive capacity. Therefore, their application in pure form to the soil is inexpedient. In this regard, in order to eliminate the rapid absorption of microelements, they are added to nitrogen, phosphorus and comprehensive fertilizers. According to Anspok (1963), the most effective and cost-effective ways to use microfertilizers are seed treatment and foliar treatment of vegetative plants.

Increasing importance is attached to foliar fertilization of vegetative plants with microfertilizers, as a means to enhance the nutrition of plants with microelements during critical vegetative phases, to quickly and effectively regulate the vital activity of plants, to reduce the loss of microfertilizers due to their immobilization by soil and to exclude the possibility of its contamination (Anspok, 1988; 1990). 
The ability of plants to absorb nutrients through overground organs and especially through leaves has been known since the middle of the last century. The mechanism of supply of nutrients, both in leaf tissue and in the root cells, is apparently quite the same and is implemented by adsorption.

The microfertilizers are especially necessary for plants under unfavorable weather conditions, when the use of nutrients from soil is hampered. All issues related to the study of microfertilizers for increasing the productivity of oil-bearing seeds, including spring rape, are very relevant and timely.

The aim of the research was to study the effect of comprehensive microfertilizers on the development of spring rape plants in the conditions of the forest-steppe of the Central Chernozem Region.

\section{The Research Tasks Included}

- To study the influence of Brassitrel microfertilizers and Brassitrel + Bortrac blend on the content of the main photosynthetic pigments (chlorophylls a, b, carotenoids (car)) and their ratio in spring rape

- To study the effect of Brassitrel microfertilizers and Brassitrel + Bortrac blend on the development of leaf area in spring rape; and

- To establish the peculiarities of crop formation and quality of spring rape seeds using Brassitrel microfertilizers and Brassitrel + Bortrac blend

\section{Methods}

The research process was based on the basic and related surveys and observation in accordance with the generally accepted method of establishing and conducting field experiments in agronomic science (Dospekhov, 1985).

The concentration of photosynthetic pigments of chlorophylls $a, b$ and carotenoids was defined by spectrophotometry, based on the ability of pigments to absorb rays of a certain wavelength using a KFK-3M strophotometer. The concentrations of the $a$ and $b$ chlorophylls were calculated according to the Vernon formula and the carotenoid concentration - by the Wettstein formula.

\section{Results}

The microfertilizers were studied according to the following scheme: (1) control; (2) Brassitrel (2kg/ha); (3) Brassitrel+Bortrac $(2 \mathrm{~kg} / \mathrm{ha}+1 \mathrm{l} / \mathrm{ha})$. The microfertilizers were introduced into the phase of the rape leaf rosette and at the beginning of the growth of the central stem. According to the calendar, this took place on May 25 and June 7. The experiments were established in three replications. The location of the plots was randomized.
Experimental work was carried out in 2016 in the Eletsk district of the Lipetsk region at the Ivanova collective farm in Kazaki village.

The soil of the experimental site is represented by leached, medium humus, heavy loam chernozem. This chernozem is characterized by the presence of the $B_{0}$ horizon leached from the carbonates.

The study of the effect of microfertilizers on the surface area of leaves of spring rape - the main assimilating apparatus of culture - is of great scientific interest. In our studies we used the areas 2.1 software. The area of the leaf surface was studied in the development phase: rosette of leaves, budding, flowering and green pod. It was noted that the application of microfertilizers positively affected the leaf surface of rape. During the rosette phase, the leaf area in application of Brassitrel was $31.26 \mathrm{~cm}^{2}$, in application of Brassitrel + Bortrac - $34.15 \mathrm{~cm}^{2}$, the increase in comparison with the control was $0.7 \mathrm{~cm}^{2}$ and $3.59 \mathrm{~cm}^{2}$, respectively. During the budding phase, the leaf surface died off in spring rape, mainly due to the lower leaves. In the control options, the decrease in the leaf surface was more intense (2.2 times). In options where microfertilizers have been applied, the area of the leaf surface reduced, but not so noticeable. A similar trend was observed in the flowering phase. In the green pod phase, the rape leaf surface continued to shrink and especially noticeably where the microfertilizers were not applied. Thus, on the control in this phase, the leaf apparatus decreased 3.4 times, in applying Brassitrel microfertilizer - 2.6 times and in applying Brassitrel + Bortrac - 2.2 times.

Microelements that are part of microfertilizers are absorbed by the plant through the leaves, influence photosynthesis, strengthening it, activate the activity of enzymes and biochemical processes in plants, extend the life of the leaves, which makes it possible to obtain higher yield.

The effect of microfertilizers on the photosynthetic potential of rape plants is shown in Table 1. The calculations show that plant processing by microelements contributed to an increase in the photosynthetic activities of the leaves and consequently, the duration of their work was longer.

When treating the rape plants with Brassitrel and Brassitrel + Bortrac microfertilizers, 7 days after their application it was found that the biosynthesis of chlorophyll was more active. The content of chlorophyll $a$ in the rape leaves in the rosette phase ranged from $0.708 \pm 0.0099 \mathrm{mg} / \mathrm{g}$ wet weight in the control against $0.734 \pm 0.0162 \mathrm{mg} / \mathrm{g}$ when treating with Brassitrel and $0.746 \pm 0.0283 \mathrm{mg} / \mathrm{g}$ - with the simultaneous application of Brassitrel + Bortrac microfertilizers. A similar situation was observed with the activity of chlorophyll $b$ in the same period. 
Table 1: The effect of microfertilizers on the photosynthetic potential of rape plants of the Ratnik variety (2016)

\begin{tabular}{llll}
\hline $\begin{array}{l}\text { Experiment option } \\
\text { of photosynthesis }\end{array}$ & & Sampling date & \\
\hline Control & Indicators & June 1 & July 1 \\
& Chl a & $0.708 \pm 0.0099$ & $0.936 \pm$ \\
& Chl b & $0.326 \pm 0.0194$ & $0.413 \pm 0.0014$ \\
& Carotinoids & $0.107 \pm 0.0056$ & $0.351 \pm 0.0016$ \\
BRASSITREL & Sum of pigments & $1.192 \pm 0.0227$ & $1.700 \pm 0.0004$ \\
& Chl a & $0.734 \pm 0.0162$ & $1.026 \pm 0.0006$ \\
& Chl b & $0.348 \pm 0.0287$ & $0.468 \pm 0.0026$ \\
BRASSITREL+ BORTRAC & Carotinoids & $0.111 \pm 0.0024$ & $0.371 \pm 0.0006$ \\
& Sum of pigments & $1.207 \pm 0.0248$ & $1.865 \pm 0.0016$ \\
& Chl a & $0.746 \pm 0.0283$ & $1.244 \pm 0.0469$ \\
& Chl b & $0.362 \pm 0.0191$ & $0.549 \pm 0.0257$ \\
& Carotinoids & $0.111 \pm 0.0065$ & $0.470 \pm 0.0040$ \\
& Sum of pigments & $1.216 \pm 0.0544$ & $2.263 \pm 0.0176$ \\
\hline
\end{tabular}

It is known that carotenoids perform a protective function in the plant body. Our studies have shown that the content of carotenoids (by weight) in rape leaves under treatment conditions insignificantly increases compared to the control, while their share does not increase in the overall structure of pigments. Their content with application of Brassitrel was $0.111 \pm 0.0024$ $\mathrm{mg} / \mathrm{g}$ wet weight and $0.111 \pm 0.0065 \mathrm{mg} / \mathrm{g}$ wet weight with the application of Brassitrel + Bortrac. This may indicate that the treatment of plants with these microfertilizers does not cause any significant disturbances in the synthesis of photosynthetic pigments in the rape leaves.

The structure of photosynthetic pigments is dominated by chlorophyll $a$, which accounts for approximately $50 \%$ of the total mass of pigments. The chlorophyll $b$ accounts for about $30 \%$ of all pigments. Carotenoids account for about $10 \%$ of the mass of pigments. In our studies, the sum of photosynthetic pigments in rape leaves when treated with Brassitrel microfertilizer varied to $1.207 \pm 0.0248 \mathrm{mg} / \mathrm{g}$ wet weight, in the Brassitrel + Bortrac option - up to $1.216 \pm 0.0544$ $\mathrm{mg} / \mathrm{g}$, while on the control these indicators were within the range of $1,192 \pm 0,0227 \mathrm{mg} / \mathrm{g}$ wet weight.

30 days after the first treatment, the photosynthetic activity of rape leaves was reinvestigated. During this period, rape was in the flowering phase and had the maximum leaf surface. We note that the use of microfertilizers under study promoted an increase in the activity of chlorophyll $a$ and chloroffil $b$, an increase in carotenoids and in the amount of pigments. The trend of the effect of Brassitrel microfertilizer and Brassitrel + Bortrac blend remained identical as when they were introduced into the rosette phase, with the only difference being that the absolute values were significantly higher.

Thus, the results of our studies indicate that the microfertilizers under study contribute to the better adaptation of the rape plants when the conditions of growth change and avoid stressful situations. This in turn positively influences the productivity of plants. The use of combined treatment of Brassitrel + Bortrac microfertilizers is an agricultural technique necessary for inclusion in modern rape technology.

\section{Discussion}

The main purpose of all agrotechnical measures, including the use of microfertilizers in spring rape crops, is to increase the productive capacity of plants, which leads to higher yields and better product quality.

The use of foliar fertilization with microfertilizers was an additional reserve for increasing yield (Table 2). It is well-known that in rape cultivation, only first-order mineral nutrition is used: nitrogen, phosphorus, potassium. However, rape is also sensitive to a lack of sulfur, boron, magnesium, copper and manganese, as well as molybdenum and zinc. The lack of these microelements causes a violation of carbohydrate metabolism and the synthesis of protein substances and reduces the resistance of plants to disease. Their use in rape cultivation is one of the important reserves of increasing yields and improving the quality of products that do not require large labor inputs.

The microfertilizers used in the experiment had their own individual composition of microelements, which had a different effect on the structure of the rape crop and, in general, on crop yields. At the same time, all microfertilizers contributed to an increase in the yield of spring rape of the Ratnik variety in comparison with the control. The use of Brassitrel microfertilizer contributed to an increase in the additional productivity of plants by $0.134 \mathrm{t} / \mathrm{ha}$, the Brassitrel + Bortrac blend - by $0.196 \mathrm{t} / \mathrm{ha}$. The additional crop was formed, most likely, due to the increase in intensity and efficiency of use of nutrients by rape plants, namely phosphorus and potassium. The microfertilizers under study facilitated the mobilization of inaccessible phosphorus and potassium from difficultly insoluble compounds in the plant rhizosphere zone. 
Table 2: Yield of spring rape depending on the treatment of plants with microfertilizers, $t /$ ha

\begin{tabular}{llll}
\hline Item No. & Option & 2016 & Addition in comparison with the control \\
\hline 1 & Control & 1.425 & - \\
2. & Brassitrel & 1.559 & 0.134 \\
3. & Brassitrel+Bortrac & 1.621 & 0.196 \\
\hline
\end{tabular}

The nutritional value of all types of food is determined by the content of proteins, fats, carbohydrates, vitamins, minerals and other biologically active compounds. The qualitative indices of oil-bearing seeds of spring rape were studied depending on the treatment of plants with microfertilizers. We note that the microfertilizers under study reduced protein (in absolute values) by $0.88 \%$ (Brassitrel) and by $1.54 \%$ (Brassitrel + Bortrac) in the seeds of spring rape. In rapeseeds, protein and fat are in inverse proportion. The microfertilizers under study significantly increased the oil content: Brassitrel - by $3.42 \%$ and Brassitrel + Bortrac - by $2.86 \%$. The increase in oil content is due to the fact that the microfertilizers contained microelements, such as boron and sulfur, which are very important for rape.

At present, strict international standards for the quality of rape seeds for processing for food and feed purposes (butter and meal) are in force. In rape oil used for food purposes, GOST establishes erucic acid at a level of no more than $3 \%$, glucosinolates - up to $1 \%$, or no more than $25 \mu \mathrm{mol}$ per $1 \mathrm{~g}$ of seeds at $9 \%$ moisture. The microfertilizers under study tended to reduce erucic acid and glucosinolates in oilseeds.

\section{Conclusion}

The use of microfertilizers under study helps rape plants to adapt better when the growth conditions change, contributes to an increase in the activity of chlorophyll a and chloroffil $b$, carotenoids, the sum of pigments and the area of the leaf assimilating surface. In addition, the use of Brassitrel microfertilizer contributed to an increase in the additional productivity of plants by $0.134 \mathrm{t} / \mathrm{ha}$, the Brassitrel + Bortrac blend - by $0.196 \mathrm{t} / \mathrm{ha}$ with a yield of $1.425 \mathrm{t} / \mathrm{ha}$ in the control option.

\section{Acknowledgement}

We thank our University for support.

\section{Author's Contributions}

All authors equally contributed in this work.

\section{Ethics}

This article is original and contains unpublished material. The corresponding author confirms that all of the other authors have read and approved the manuscript and there are no ethical issues involved.

\section{References}

Anspok, P.I., 1988. Soderzhaniye mikroelementov v pochvakh i neobkhodimost' ikh primeneniya [The content of microelements in soils and the need for their application]. Khimizatsiya Sel'skogo Khozyaystva, 2: 73-75.

Anspok, P.I., 1990. Mikroudobreniya. Spravochnic [Microfertilizers. Guide.]. 2nd Edn., Agropromizat, Mod. and Suppl Leningrad, pp: 272.

Anspok, P.I., 1963. Sposoby i dozy primeneniya mikroelementov v Latviyskoy SSR i ikh vliyaniye na urozhay i kachestvo sel'skokhozyaystvennykh kul'tur [Ways and doses of application of microelements in the Latvian SSR and their influence on crop and quality of agricultural crops]. Microelements Agric. Med. Kiev.

Belikov, P.S. and G.A. Dmitriyeva, 1992. Fiziologiya Rasteniy. [Plant physiology.] Monograph. 1st Edn., Moscow: RUDN, pp: 248.

Dospekhov, B.A., 1985. Metodika Polevoy Obrabotki Rezul'tatov opyta (s Osnovami Statisticheskoy Obrabotki Rezul'tatov Issledovaniy) [The Method of Field Processing of the Results of the Experiment (with the Basics of Statistical Processing of the Results of the Research)]. 1st Edn., Agropromizdat, Moscow, pp: 351.

Petrov, B.A. and N.F. Seliverstov, 1998. Mineral'noye pitaniye rasteniy. [Mineral nutrition of plants.] Reference guide for gardeners and farmers. Ekaterinburg.

Potutaeva, Y.A., 1963. Effektivnost' razlichnykh form molibdenovykh udobreniy v svyazi so sposobami ikh vneseniya [Effectiveness of various forms of molybdenum fertilizers in connection with the methods of their application]. Microelements Agric. Med. Kiev.

Rinkis, G.Y., 1975. Mikroelementy v komplekse mineral'nogo pitaniya rasteniy. [Microelements in the complex of mineral nutrition of plants]. Riga.

Sinyagin, I.I., 1970. Ploshchadi pitaniya rasteniy. [Areas of plant nutrition.]. Moscow: Rosselkhozizdat.

Vlasyuk, P.A., 1969. Biologicheskiye elementy v zhiznedeyatel'nosti rasteniy [Biological elements in the life of plants]. Kiev: Naukova Dumka.

Yagodin, B.A., 1989. Agrochemistry. 1st Edn., Agropromizdat, Moscow, pp: 656. 